\title{
Children's Forum and Citizenship Education Among Adolescents
}

\author{
Sri Yuliani ${ }^{1}$, Rahesli Humsona ${ }^{2}$ \\ ${ }^{1}$ Department of Public Administration of Faculty of Social and Political Sciences, Universitas Sebelas Maret, Jl. Ir. Sutami \\ 36 A, Surakarta, Indonesia \\ ${ }^{2}$ Department of Sociology of Faculty of Social and Political Sciences, Universitas Sebelas Maret, Jl. Ir. Sutami 36 A, \\ Surakarta, Indonesia \\ sriyuliani63@staff.uns.ac.id,
}

Keywords: Children's Forum, Children's Participation, Citizenship Education, Adolescents

\begin{abstract}
Children's voice is considered as unnecessary to be taken into account in development planning up to now, while the number of children is nearly a third of total world populations. Children's Forum is established by the government as the fulfillment of The United Nations Convention on the Rights of the Child to ensure child participation right in development. This research aimed to study the strategic role of Surakarta Children's Forum (Indonesian: Forum Anak Surakarta or FAS) as children's participation media in development and citizen education medium all at once in adolescents, and supporting and inhibiting factor in undertaking the function. This study was a descriptive qualitative research. The informants were determined purposively consisting of FAS members and builders and facilitating NGO, and data analysis was conducted by using an interactive model of analysis. The result showed that FAS had functioned as a means of citizenship education among children and peer adolescents through participating in Development Planning Discussion and becoming peer educator for socializing and introducing public issues related to children's problem. Children's internal capacity becomes a factor supporting FAS's success as a citizenship education media. Constraints originated more from external factor in the form of State Civil Apparatus' low consciousness of children's rights and the builder's inadequate capacity of reinforcing the capacity of Children's forum.
\end{abstract}

\section{INTRODUCTION}

World population dominated with young age is the key factor to the successful mission of Sustainable Development Goals/SDGs to realize the economic growth, the improved life quality, and social welfare and justice. World population number, according to World Population Prospects' Report of 2017, nearly reaches 7.6 billions. Twenty six percent of the figure is 0-14 year age and 16 percent of 15-24 years. Almost $50 \%$ of child and youth populations in the world live in developing countries (1.8 billion children and 1.1 billions youth). About $87 \%$ of children and youths living in developing countries have limited access to resource, education, training, job opportunity, and business opportunity (World Population Prospects 2017; Youth Participation in Development A Guide for Development Agencies and Policy Makers). As a part of nearly a half of world population, child and youth's voice and aspiration should be heard and accommodated obligatorily in development planning. World Bank's Report entitled "The Way Forward: Inclusive Youth Policy and Institutions, Breaking the Barriers To Youth Inclusion" concluded that engaging youths in decision making and public activity related to child problem can support the growth of young generations who have capacity to contribute directly to realizing a stable and sustainable economic and political condition.

In the context of democratic political order, the child is a part of citizens who has specific need and different interest from adult. For that reason, children's participation in development program planning and implementation become a must for democratic government. To this point, child's voice is heard inadequately in public decision making with an assumption that child has not had sufficient capacity to be engaged in activities in the political domain (Roche, 1999). A survey conducted by UN IANYD on August 2012 found that majority of 13,000 respondents from 186 countries stated that limited opportunity constrains the youth from 
participating effectively in public decision process (Youth, Political Participation and Decision-Making, UNDP).

Article 12 of Convention on the Rights of the Child (CRC) mandates the states to ratify the convention to ensure the children's right to express their opinion freely regarding everything related to or impacting on children, according to the children's age and maturity. CRC defines a child since in the womb to 18 year-age. Indonesia as a state that has ratified CRC assumes an obligation of fulfilling the children's right to be engaged in public decision making related to children's right fulfillment and protection. Children's Forum is the forum established by the government as a medium of accommodating children's participation in development. The children engaged in public decision making are those aged 14-18 years or adolescents.

Adolescents' participation in Children's Forum makes them conceiving public issues related to children's problem and need, and practicing their ability of channeling their proposed solution in Musyawarah Perencanaan Pembangunan (Development Planning Discussion) forum. Checkoway et al (2005) stated that children's participation in public decision making forum can improve the children's awareness as citizen with public rights and obligations to be fulfilled. Thus, Children's Forum indirectly plays a strategic role in citizen education for adolescents. This article aims to study further the strategic role of Forum Anak Surakarta (FAS) in citizenship education among adolescents and the factors affecting FAS's capacity of playing the role.

\section{METHODS}

This study used descriptive qualitative research. The informants were selected purposively consisting of 23 children affiliated with FAS; FAS's Facilitator and Builder; and NGOs Facilitator. This research employed secondary data source related to FAS taken from document, archive, government regulation, newspaper, magazine, video, and other sources either printed or online. Data collection was carried out using observation, in-depth interview, and focus group discussion. Data analysis was carried out using interactive model (Miles and Huberman, 1992) consisting of three components: data reduction, data display, and conclusion drawing.

\section{RESULT AND DISCUSSION}

\subsection{Children's Participation in Development}

Participation is a decision-making process impacting on an individual or a community's life (Hart, 1992). Children's participation in public policy is the process of engaging children in decision-making affecting their life, including in any attempt the children take to take initiative and to organize policy issues related to children's interest (Checkoway et al, 2005; Brady, 2007). CRC defines children's participation as ongoing processes, which include information-sharing and dialogue between children and adults based on mutual respect, and in which children can learn how their views and those of adults are taken into account and shape the outcome of such processes.

Hill (in Thomas, 2007) formulates children's participation as "the direct involvement of children in decision-making"; participation is not merely consultation or "seeking views". In practice, children's participation is still limited to comply with the procedure or formality, or as Hart (1992) calls, tokenism, rather than active participation. Participation is often defined as only being heard and being consulted with. Active participation occurs when children are sure that their participation will result in a change (Sinclair in Thomas 2007). Effective or active participation can be interpreted from two sides: social activity and activity affecting or creating social or political change through public decision-making process (Sotkasiira, Haikkola and Horelli: 2010).

Children participation will be effective when it is conceived as a process rather than incidental activity. Sanders and Mace's (2006) study found that participation models are not children-friendly or sensitive, for example, conferencing model inhibiting the screening of children's voice. Matthew, Kirby and Bryson (in Cavet and Sloper, 2004) argue that complex bureaucratic organizational and internal politic factors also inhibit children's participation. In addition, adult's inadequate confidence in children's ability will make the program "adult focus" (Roche, 1999; Masri, 2017). Checkoway (2011) states that "adult focus"- policy is due to adults' assumption that the youths make public decision less competently. Adultism is a result from an assumption that adults are always better than children or adolescents. Elders are entitled to act representing the children's interest with an assumption that children has not been matured enough to make the best decision for themselves. In turn, adultism results in many 
agendas and program implementation processes controlled by adults. Therefore, Shier (in Thomas, 2007) states that active participation can occur only when adults want to share their power by means of delegating some of their power to and trusting the children.

\subsection{Citizenship Education in Adolescents}

Participation will give the children the opportunity for affecting public policy concerning their interests and rights. Stoecklin and Bonvin (2014) formulate children's participation as a process and in order to develop capability and fulfill human rights. VillaTorres (2015) defines participation as civil and political rights (e.g. participation in general election) and economic, cultural, and social rights (participation in development agenda and program planning and implementation). Children's participation as the form of social and political rights fulfillment is a strategic medium for citizenship education. Citizenship education is a process of educating children earlier in order to be clearthinking and enlightened citizen, thereby capable of participating in public decision making (Citizenship Education for the 21st Century - Unesco).

Citizenship concept refers to political and social rights and obligation that the citizens should comply with to make democratic order running well. The general characteristics of citizenship can be seen from participation in general election, the way of they expressing opinion or aspiration in public forum, or campaigning for public awareness of crucial problem impacting on public welfare (Lister, 2007; Bellamy, 2008; Doppen et al,2014). Citizenship, according to Bellamy (2008), consists of three components: affiliation with democratic political community (pertaining to an individual's membership or nationality status), collective right and benefit obtained from nationality status (rights needed for an individual to participate in democratic decision), and participation in social, economic, and political processes in a community. These three components of citizenship put a foundation for civic equality. For that reason, Bellamy formulates citizenship as a civic equality condition in which all citizens have equal right to enjoy public facility provided by state and also equal obligation to promote and to maintain democratic citizenship.

Marshall (in Roche, 1999) formulates citizenship consisting of three elements: civil, social, and politics. Civil element pertains to law enforcement and personal freedom including the freedom of expression. Political element is related to the right to participate in political process or vote. Meanwhile, the social element of citizenship raises not only economic welfare issue but also complete right to social heritage and right to live in dignity according to human life standard. The social element of citizenship or social right is crucial to the fulfillment of civil and political rights, particularly for the marginalized group in resource and politics, in this case including children and adolescents (Lister in Roche, 1999).

Viewing from the political element, adolescent citizens are entitled to be engaged in decision making pertaining to children's interest and viewing from social element, adolescents is entitled to get social and economic welfare are also entitled to be recognized for their social identity. Geijsel (2012) suggests that classical theory about political interpretation of citizenship defines adolescent as the future citizen. As a result, citizenship study on adolescents focuses more on reinforcing political competency necessary in adulthood in order to be prepared for participating within society. For example, civil education is given to equip them with political participation, determine choice in general election and develop democratic attitude. Geijsel argues that adolescents become as citizens when they have participated in social activities that requiring them to interact with many parties. In addition to political competency reinforcement, social competency is also needed to educate adolescents in order to be aware of their position and social role amid society.

Some studies show that youth's participation in development can support the youth's social development through improving knowledge, skill, social value, and civil competency. Such the competencies help reinforce the youth's role as citizen and civil society (Checkoway et al, 2005). United Nations' report entitled "World Youth Report 2015 - Youth Civic Engagement" mentioned that youth's participation in development contributes to the children's personal development, welfare improvement, and social injustice problem solving, and furthermore can grow democratic citizenship. Democratic citizenship conceives youths' participation as their opportunity of showing off their capacity as social and political actors in society. This report recommends citizenship education to start from adolescent and to continue in a lifetime.

\subsection{Children's Forum and Citizenship Education in Surakarta City}

Children's Forum is a communication forum organized by children and built by the government. It can be used as a medium for children's, both individuals or as a representative from a group. In Surakarta City, Children's Forum has been established in all of 51 kelurahan and 5 kecamatan 
(sub-districts). Forum Anak Surakarta (FAS) is Children's Forum at municipal level that established in 2006. FAS has three principles: a) nondiscrimination or universality, b) best interest for children, c) children appreciation, d) opened and not binding. FAS's membership consist of 12-18 years old children from Children's Forums in Surakarta and the FAS alumni but still need for help and being as a facilitator of FAS.

Children's forum serves as a media for hearing and fulfilling children's voice, opinion, desire, and the needs of aspirations in the development process (Surakarta Mayor's Regulation Number 3-B of 2013 about General Guidelines of Children's Participation Development in Surakarta City Development). In addition, Children's Forum is also functioned: a) as a medium for monitoring the implementation of Children's right fulfillment, b) as a medium of socializing activity program related to children's right in peer environment, c) as a medium of voicing children's aspiration, d) to encourage the children's participation in decision making process, and e) to encourage children to develop their potency actively (National Children's Forum Guidelines, 2012).

FAS enacts as a strategic role for citizenship education which is viewed from citizenship basic elements: civil and political right function through its participation in Musyawarah Perencanaan Pembangunan (Musrenbang) and social function as a peer educator in making the public aware of children issues.

Firstly, the strategic role of FAS enacts to civil society and political rights through participation in Musrenbang. The basic objective of the establishment of Children's Forum was to make the children participate in development planning. Children's participation in development planning according to Surakarta Mayor's Regulation Number 3-B of 2013 about General Guidelines of Children's Participation Development in Surakarta City is defined as children's engagement to express their aspiration and it needs decision making process through Musyawarah Perencanaan Pembangunan (Musrenbang) stages concerning everything related to themselves and implemented based on collective consciousness, understanding, and willingness. Therefore the children can enjoy the benefits from it. FAS participation in Musrenbang has begun since 2013 through the establishment of children's forum to be one of sectoral communities engaged as participator in Surakarta City (Surakarta Mayor's Regulation No. 18-A of 2012 about Guidelines and Technical Instruction of Development Planning Discussion Organization in Surakarta City during 2013). FAS as city-level children's forum plays a strategic role as it accommodates the aspiration of all children's forums from kelurahan to sub district level to be delivered in Musrenbang Forum at Local Apparatus Organization and City-Level Development Planning Discussion (Musrenbangkot) or Local Government's Work Plan forum. FAS can be said as serving advocator to voice the children's aspirations, needs and interests before the policy maker, such as Dinas Pemberdayaan Perempuan, Pemberdayaan Masyarakat, dan Perlindungan Anak (the Agency for Community Empowerment, Women Empowerment and Child Protection) and Bappeda (Regional Development Planning Board of Surakarta City). Participating in Musrenbang is a way of growing adolescents' awareness of civil and political rights earlier and of practicing democratic function and values. The FAS participation advantages in Musrenbang are: a) being advocator to channel the children's voice and right; b) knowing more who and what the governmental apparatus (mayor and related institutions) do; c) growing insight into and perspective on politics and making the government more opened; and e) speaking and expressing opinion more bravely in public forum (FGD with FAS, on 25-8-2017 and 30-3-2018).

Secondly, FAS plays its strategic role in citizenship education through its function as a peer educator. Surakarta City Government launched a peer educator program in 2016 to deal with children's problem, particularly children abuse. This peer educator is expected to practice other children and fortify themselves from violence threat. Peer education is considered as an effective way to deal with violence against children when children usually can tell more about their problems to their peer (solo.tribunnews.com, 2016). Peer educators are recruited from Children's Forum members and alumni. FAS receives training from NGO in order to be prepared for undertaking the functions of making the public aware of children's right and facilitating the children and peer encountering children's problems such as children abuse, drug abuse hazard, early marriage, adolescent reproduction health, and others. As a peer educator, the functions that are undertaken by FAS which are: socializing to schools ranging from Elementary to Senior High Schools about children abuse or bullying; campaigning for the children's rights, informing the effect of violence on children, drug abuse, early marriage, and adolescent reproduction health, HIV-AIDS, antismoking, and other children problems. FAS campaigns for various problem that threated the children's future (FGD with FAS and Kakak Foundation on 30-3-2018 and 4-4-2018, many sources from youtube; FAS facebook and twitter accounts).

Many factors affect the strategic role of FAS in citizenship education, both from internal aspects or external aspects. From the internal aspect, it can be 
analyzed that nearly all children affiliated with FAS have capacity to be engaged actively in Development Planning Discussion as they have adequate knowledge on their rights and their abilities of communicating and expressing their opinion in public forum (FGD with FAS 25-8-2017 and 30-32018). Constraint originates more from external factor: Surakarta City Government's commitment to actually engaging FAS to make the participants active in Development Planning Discussion. So far, FAS engagement in Development Planning Discussion is still limited to fulfilling the legal formal precondition requiring the presence of FAS as one of sectoral communities in Development Planning Discussion (Interview with FAS members and facilitator).

FAS also has potential capacity to make peer educator's role for socializing children issues and problems. As Children's Forum at city level, FAS has received some peer educator trainings. They utilize social media smartly to broadcast Children's Forum activity and campaign for the fulfillment of children's right and protection. The constraints of the Children's Forum encounter as peer educator come from the unbalance between FAS human resource number and the number of children that should receive peer training. The number of peer educators recruited from Children's Forum consists of only 70 children to provide training and facilitation for 164.000 children in Surakarta distributed in 51 Kelurahans in Surakarta City (solo.tribunnews.com, 2016). Another inhibiting factor is not all Children's Forums in Surakarta city have received peer training and education then the ten peer educators recruited have not been able yet to undertake their duty. They still need peer education training or peer counselor to facilitate the children victim of abuse (koransolo.co, 2016). Moreover, builder and facilitator of Children's Forum conceive children and adolescent's world inadequately and have not understood yet the technique of motivating and facilitating children in order to be capable of serving as peer educator (Interview with Children's Forum and NGO members).

\section{CONCLUSIONS}

The role of Children's Forum in citizenship education is through their engagement in Development Planning Discussion and as peer educator. The participation of Children's Forum in Development Planning Discussion becomes an effective way of making the people aware of civil and political rights among adolescents as it participates in Development Planning Discussion practicing the adolescents to express children's aspiration and interest bravely in order to be accommodated in city development budgeting plan. Meanwhile, the role of peer educator is the form of citizenship education that viewed from social aspect. As a peer educator, Children's Forum is responsible for making the peers aware of and practicing the children's right and obligation fulfillment. The function of peer educator requires adolescents to interact with peer children and adolescents also with other stakeholders. This function sharpens the ability of communicating and establishing relation with many stakeholders, thereby impacting on adolescents' social capacity development directly.

From the internal capacity, children's forum particularly Forum Anak Surakarta - has adequate competency to engage actively in Musrenbang and become peer educator. Constraints come more from external factor including the State Civil Apparatus' low awareness of children's right impacting on Children's Forum participation in Musrenbang still limited to fulfilling formality and the capacity of Children's forum builder to reinforce Children's Forum capacity.

This research concludes that the effectiveness of Children's Forum as a citizen education media is not only affected by children's internal capacity but also the determinant factor such as State Civil Apparatus's awareness of the importance on fulfilling children's right and protection. For that reason, this research recommends the need for integrating the perspective on children's right and obligation to entire policy process of local development, particularly in Surakarta City. This strategy can be realized when supported by the presence of State Civil Apparatus aware of children's rights and children-responsive budgeting system.

\section{REFERENCES}

Bellamy, Richard. 2008. Citizenship: A Very Short Introduction. Oxford University Press

Brady, Bernadine. 2007. Developing Children's Participation : Lessons from a Participatory IT Project. Children \& Society. Volume 21 pp.31-41

Cavet, J and Sloper, P. 2004. The participation of children and young people in decisions about UK service development. Social Policy Research Unit, University of York, Heslington, York, UK

Cegah Kekerasan Anak, Pemkot Solo Latih 'Pendidik Sebaya'. 2016. Retrieved from http://solo.tribunnews.com/2016/05/11/cegahkekerasan-anak-pemkot-solo-latih-pendidik-sebaya 
Checkoway, Barry., Allison ,Tanene., Montoya, Colleen.2005. Youth participation in public policy at themunicipal level. Children and Youth Services Review 27 (2005) 1149- 1162

Checkoway, Barry. 2011. What is youth participation? Children and Youth Services Review 33 (2011) 340345. Elsevier

Citizenship Education for the 21st Century. Unesco. http://www.unesco.org/education/tlsf/mods/ theme_b/ interact/ mod07task03/appendix.htm

Convention on the Rights of the Child. Retrieved from http://www.ohchr.org/Documents/ Professional Interest/crc.pdf

Doppen, Frans H., Feinberg, Joseph R., ArrowoodSchultheis , Chelsie M. Young Adolescents' Knowledge and Notions of Citizenship. 2014. Citizenship, Social and Economics Education. Volume 13 Number 1 . www.wwwords.co.uk/CSEE

Facebook Forum Anak Surakarta. https://idid.facebook.com/FASForum-Anak-Surakarta175414839214436/

Geijsel, Femke, Guuske Ledoux, Rene Reumerman, Geert ten Dam.Citizenship. Young people's daily lives: differences in citizenship competences of adolescents in the Netherlands. 2012. Journal of Youth Studies, 15:6, 711-729

Hart, Roger.A., 1992. Children's Participation : From Tokenism to Citizenship. UNICEF International Child Development Centre.

Kota Solo Layak Anak Pemkot Solo Siapkan \&0 Pendidik Sebaya. http://www. koransolo.co/ 2016/03/05/kotalayak-anak-pemkot-solo-siapkan-70-pendidik-sebaya61966. Diunduh 18-2-2018

Lister, Ruth. 2007. Why Citizenship: Where, When and How Children? Theoretical Inquiries in Law. Vol. 8:693

Masri, S. Saridar . 2017. Integrating youth in city planning: Developing a participatory tool toward a child-friendly vision of Eastern Wastani- Saida, Alexandria Engineering Journal (2017). Elsevier http://dx.doi.org/10.1016/j.aej.2017.01.023

Miles, M dan Huberman, M., 1992. Analisis Data Kualitatif. UI Press. Jakarta.

Pedoman Umum Forum Anak Nasional 2012. Retrieved from http://forumanak.id/download/2907/

Peraturan Walikota Surakarta No. 18-A Tahun 2012 tentang Pedoman Penyelenggaraan dan Petunjuk Tehnis Pelaksanaan Musyawarah Perencanaan Pembangunan Kota Surakarta Tahun 2013.

Peraturan Walikota Surakarta Nomor 3-B Tahun 2013 tentang Pedoman Umum Pengembangan Partisipasi Anak Dalam Pembangunan di Kota Surakarta.

Roche, Jeremy. 1999. Children: Rights, Participation and Citizenship. Childhood. Vol.6 (4) : 475-493. Sage Publications

Sanders, Robert dan Mace, Sam. 2006. Agency Policy and the Participation of Children and Young People in the Child Protection Process. Child Abuse Review Vol.15:89-109. Published online in Wiley InterScience (www.interscience.wiley.com).
Sotkasiira, Tina., Haikkola, Lotta, dan Horelli, Liisa. Building towards effective Participation : A learningbased network approach to youth participation, dalam Percy-Smith, Barry dan Thomas, Nigel. A handbook of children and young people's participation : perspectives from theory and practice. First published 2010 by Routledge 2 Park Square, Milton Park, Abingdon, Oxon

Stoecklin, D and Bonvin, J-M. Editors. 2014. Children's Rights and the Capability Approach : Challenges and Prospects. Springer Science+Business Media. Dordrecht

The Way Forward : Inclusive Youth Policy and Institutions, Breaking the Barriers To Youth Inclusion. World Bank. Retrieved from http://www.worldbank.org/content/ dam/Worldbank/document/MNA/tunisia/breaking_the _barriers_to_youth_inclusion_eng_chap6.pdf

Thomas, Nigel. 2007. Towards a Theory of Children's Participation. International Journal of Children's Rights 15 (2007) 199-218

Twitter Forum Anak Surakarta. https://twitter.com/fasurakarta.

Villa-Torres, Laura dan Svanemyr, Joar. 2015. Ensuring Youth's Right to Participation and Promotion of Youth Leadership in the Development of Sexual and Reproductive Health Policies and Programs. Journal of Adolescent Health 56 (2015) S51eS57. Elsevier.

World Population Prospects The 2017 Revision , Key Findings and Advance Tables. United Nations. Bedminster Press . New York.

World Youth Report 2015, Youth Civic Engagement. Published by the United Nations New York

Youth Participation in Development. A Guide for Development Agencies and Policy Makers. Published by the DFID-CSO Youth Working Group. Retrieved from http://www.restlessassets.org/ wl/ ?id= uma ETRcmVyn2VEpSrxu7JWWkHom5Ryli

Youth, Political Participation and Decision-Making. United Nations. Retrieved from http://www.un.org/esa/ socdev/documents/youth/factsheets/youth-political-participation.pdf. 